\title{
Midline basifrontal solid hemangioblastoma in non von hippel lindau syndrome patient
}

\author{
Avijit Sarkari, Deepak Agrawal \\ Department of Neurosurgery and Gamma Knife, All India Institute of Medical Sciences, New Delhi, India
}

\begin{abstract}
Supratentorial location of hemangioblastoma is very rare. The authors report a case a 45 year old female who had sporadic solid supratentorial hemangioblastoma and who made a complete recovery following gross total removal of the tumor.
\end{abstract}

Key words: Hemangioblastoma, supratentorial, basifrontal

\section{Introduction}

Hemangioblastomas are histologically benign, rare, neuroaxial highly vascular tumors composed of a mixture of neoplastic stromal cells embedded in a rich capillary network ${ }^{[1]}$ that occur either sporadically $(67 \%$ of cases) or as part of von Hippel-Lindau disease (VHL; $33 \%$ of cases). ${ }^{[2,3]}$ They can be found in any part of the central nervous system but most often are located in the posterior fossa or spinal cord. ${ }^{[4]} \mathrm{A}$ supratentorial location is very rare. ${ }^{[5-8]}$ About 152 cases have only been described in the literature out of which 82 had VHL syndrome. ${ }^{[5]}$ We report a case of sporadic solid supratentorial hemangioblastoma with relevant review of literature.

\section{Case Report}

A 45 year old female presented to our institution with complaints of mild, holocranial, continuous headache for one year. Patient had no other neurological deficits-all cranial nerves and vision was normal. The patient did not have polycythemia. CT scan showed isodense lesion in midline basifrontal lesion well enhancing with contrast.

\begin{tabular}{|l|l|}
\hline \multicolumn{2}{|c|}{ Access this article online } \\
\hline Quick Response Code: & Website: \\
\hline & www.ruralneuropractice.com \\
\cline { 2 - 3 } & \\
\hline & \\
\hline
\end{tabular}

On MRI lesion was $4.3 \times 5.5 \times 4.6 \mathrm{~cm}$ midline basifrontal isointense on T1WI, hyperintense on T2WI heterogenous, solid with marked enhancement on gadolinium. Neither any definite flow voids were visible nor was dural-tail sign evident. There was marked perilesional edema.

Intra-operatively the tumor was found to be intra-axial, purplish, highly vascular having a good plane with the normal surrounding brain with multiple feeders, one large feeder from the anterior cerebral artery. Gross total excision was done. Histopathological diagnosis was of hemangioblastoma.

The patient did not have any family history of VHL syndrome and further investigations done did not diagnose her from having it.

\section{Discussion}

Supratentorial hemangioblastomas are rarely encountered in neurosurgical practice. These tumors usually occur in adulthood, mainly fourth decade ${ }^{[5]}$ but congenital and infant supratentorial cystic hemangioblastomas have been reported. ${ }^{[9]}$ Hemangioblastomas have a tendency to be cystic lesions with a mural nodule. Pure solid tumors are less common than cystic tumors. ${ }^{[8]}$

Peritumoral cysts have been demonstrated to originate from peritumoral edema in central nervous system hemangioblastomas. ${ }^{[10]}$ The extent of edema is not linked to the size of the tumor and it does not always lead to the formation of a cyst over time. ${ }^{[5]}$ Edema is

Address for correspondence:

Dr. Deepak Agrawal, Associate Professor, Department of Neurosurgery, All India Institute of Medical Sciences Medical Sciences,

New Delhi-110 029 India. E-mail: drdeepak@gmail.com 
thought to be the result of the diffusion of a plasma ultrafiltrate from the interstitial space of the tumor to the surrounding brain, and when the absorptive capacities of the surrounding tissue are exceeded, a cyst develops. Compared with the cerebellum, the cerebrum offers a bigger volume for edema diffusion. Vasogenic edema especially diffuses along white-matter tracts and even along those of optic system have been described. ${ }^{[1]]}$ This explains why cyst formation should be less frequent in the supratentorial region compared with the posterior fossa and why extended areas of edema might occur with small tumors. ${ }^{[5,10]}$

"Giant" supratentorial hemangioblastomas $(>3 \mathrm{~cm} 3)$ have been reported in the literature. ${ }^{[12]}$ They appear to be more frequent in the parasagittal region. They do not often develop major cysts. This might explain their large size at diagnosis because mass effect and resulting symptoms are due mainly to the tumor itself. ${ }^{[5]}$

On an unenhanced scan, the mural nodule or the solid part of the tumor is isodense to brain tissue. CT and magnetic resonance imaging can easily detect characteristics such as whether the tumor is pure solid, cystic or mural nodule, and any peritumoral edema. On contrast enhanced CT, the solid part, mural nodule and cyst wall may hold the dye diffusely. Peritumoral edema is common in these tumors. Calcification has not been reported..$^{[7]}$ Radiological appearance of the supratentorial solid hemangioblastomas may mimic meningiomas at similar locations if located at the convexity. ${ }^{[13]}$

The lesion is isointense or hypointense on T1-weighted images and hyperintense on T2-weighted images. ${ }^{[14]}$ Transition from a solid tumor to a classic cystic tumor with a small mural nodule has been reported. Occasionally, signal in solid tumor components can be heterogeneous on T1-weighted images, with areas of increased signal within the solid portion. These regions may represent lipid in the stromal cells or methemoglobin from hemorrhage. ${ }^{[14]}$ Pathologic dilated vessels can be demonstrated as hyperintense structures on flow-enhanced gadolinium studies. MRI with intravenous contrast enhancement shows enhancing nodules well because of their vascularity. ${ }^{[15]}$

On diffusion weighted imaging (DWI), the margins of these tumors are not well defined and even their presence is unclear. ${ }^{[16]}$ The solid enhancing portions have lower signal on DWI and high apparent diffusion co-efficient (ADC). This is in comparison to other cerebellar tumors in which solid and enhancing portions are isointense and/or give high signal on DWI. ${ }^{[17]}$
On proton MRS, high mobile lipids (Lip) peaks between 0.9 and $1.4 \mathrm{ppm}$, are found which are compatible with histologically proven lipids in the tumor. No lactate peak is present and the creatine/phosphocreatine peak is low. Choline-containing compounds are increased. Absence of $\mathrm{N}$-acetylaspartate peak indicates non-neurogenic origin of tumor. ${ }^{[18]}$ It is hypothesized that combined with the absence of the necrotic component on magnetic resonance imaging, this Lip peak on proton MRS could be the characteristic pattern of hemangioblastoma. These unique results of proton MRS can play an important role in the differential diagnosis of intracranial hemangioblastoma. ${ }^{[18]}$

The present case is an example of a giant solid supratentorial hemangioblastoma presenting with subtle headache and no other stigmata suggestive of hemangioblastoma with a confusing radiology. The absences of cyst and subtle neurological features have a logical explanation in the relevant literature available and such cases may well be diagnosed pre-operatively with clinical application of advances in radiodiagnosis.

\section{References}

1. Vortmeyer AO, Gnarra JR, Emmert-Buck MR, Katz D, Linehan WM, Oldfield EH, et al. von Hippel-Lindau gene deletion detected in the stromal cell component of a cerebellar hemangioblastoma associated with von Hippel-Lindau disease. Hum Pathol 1997;28:540-3.

2. Richard S, David P, Marsot-Dupuch K, Giraud S, Béroud C, Resche F. Central nervous system hemangioblastomas, endolymphatic sac tumors, and von Hippel-Lindau disease. Neurosurg Rev 2000;23:1-22.

3. Richard S, Graff J, Lindau J, Resche F. Von Hippel-Lindau disease. Lancet. 2004;363:1231-4.

4. Wanebo JE, Lonser RR, Glenn GM, Oldfield EH. The natural history of hemangioblastomas of the central nervous system in patients with von Hippel-Lindau disease. J Neurosurg 2003;98:82-94.

5. Peyre M, David P, Van Effenterre R, François P, Thys M, Emery E, et al. Natural history of supratentorial hemangioblastomas in von HippelLindau disease. Neurosurgery 2010;67:577-87.

6. Diehl PR, Symon L. Supratentorial intraventricular hemangioblastoma: Case report and review of the literature. Surg Neurol 1981;15:435-43,

7. Rengachary SS, Blount JP. Hemangioblastomas. In Wilkins RH, Rengachary SS (ed.), Neurosurgery, second edition. McGraw-Hill: NewYork; p. 1205-19.

8. Sharma RR, Cast IP, O'Brien C. Supratentorial haemangioblastoma not associated with Von Hippel Lindau complex or polycytemia: Case report and literature review. Br J Neurosurg 1985;9:81-4.

9. Karabagli H, Karabagli P, Alpman A, Durmaz B. Congenital supratentorial cystic hemangioblastoma. Case report and review of the literature. J Neurosurg 2007;107:515-8.

10. Lonser RR, Vortmeyer AO, Butman JA, Glasker S, Finn MA, Ammerman JM, et al. Edema is a precursor to central nervous system peritumoral cyst formation. Ann Neurol. 2005;58:392-9.

11. Baggenstos M, Chew E, Butman JA, Oldfield EH, Lonser RR. Progressive peritumoral edema defining the optic fibers and resulting in reversible visual loss. J Neurosurg. 2008;109:313-7.

12. Takeuchi H, Hashimoto N, Kitai R, Kubota T. A report of supratentorial leptomeningeal hemangioblastoma and a literature review. Neuropathology. 2008;28:98-102.

13. Iyigun OL, Cokluk C, Aydin K, Yildiz L, Rakunt C, Celik F. Supratentorial leptomeningeal hemangioblastoma mimicking a meningioma without 
Von Hippel-Lindau complex. Turkish Neurosurg 2004;14:25-7.

14. Sanders WP, Ausman JI, Dujovny M, Madrazo BL, Ho KL, Jack CR Jr, et al. Ultrasonic features of two cases of spinal cord hemangioblastoma. Surg Neurol 1986;26:453-6.

15. Ho VB, Smirniotopoulos JG, Murphy FM, Rushing EJ. Radiologicpathologic correlation: Hemangioblastoma. AJNR Am J Neuroradiol 1992;13:1343-52.

16. Okamato K, Ito J, Ishikawa K, Sakai K, Tokiguchi S. Diffusion-weighted echo-planar MR imaging in differential diagnosis of brain tumors and tumor-like conditions. Eur Radiol 2000;10:1342-50.
17. QuaderyFA, OkamotoK. Diffusion-weightedMRI of haemangioblastomas and other cerebellar tumours. Neuroradiology 2003;45:212-9.

18. Isobe T, Yamamoto T, Akutsu H, Anno I, Shiigai M, Zaboronok A, et al. Proton magnetic resonance spectroscopy findings of hemangioblastoma. Jpn J Radiol 2010;28:318-21.

How to cite this article: Sarkari A, Agrawal D. Midline basifrontal solid hemangioblastoma in non von hippel lindau syndrome patient. J Neurosci Rural Pract 2012;3:399-401.

Source of Support: Nil. Conflict of Interest: None declared. 